Original Article

Received/Accepted

Dates

19.09.2021/15.10.2021

DOI

10.52096/jsrbs.6.1.7.13.28
Journal of Social Research and Behavioral Sciences

Sosyal Araştırmalar ve Davranış Bilimleri Dergisi

ISSN:2149-178X

Volume: 7 Issue: 13 Year: 2021

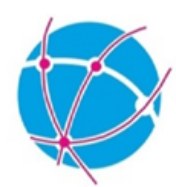

\title{
Pandemi Sürecinde Müziğin İyileştirici Etkileri
}

\author{
Elvan KARAKOÇ \\ Çankırı Karatekin Üniversitesi \\ Sanat Tasarım ve Mimarlık Fakültesi \\ Müzik Bölümü
}

\section{Özet}

Geçmişten günümüze sanatın, müziğin fiziksel, ruhsal, tedavi edici etkileri olduğu yapılan araştırmalarla bilinmektedir. Müzikle terapi denilen bu alanla, tıpta pek çok dalda insanları tedavi etmek için müziğin sakinleştirici, iyileştirici, birleştirici etkileri kullanılmaktadır. Tüm dünya ülkeleri olarak her alanda tarih sayfalarına geçtiğimiz bu pandemi sürecinde müziğin birleştirici, kaynaştırcı, iyileştirici, yenileyici, tedavi edici, etkileri bir kez daha farkedilmektedir. İnsanların sağlı̆̆ını korumak, onları kitlesel ölümlerden kurtarmak adına devletler, sosyal, kültürel, ekonomi, eğitim her açıdan pek çok alanda kısıtlamalara gitmek zorunda kalmıştır. Evde kal uygulamasıyla, herkesin kendi aile hayatında, dış dünyadan izole bir şekilde yaşayarak covid-19 virüsünün bulaştırıcı etkilerinden uzaklaştırıldığı böylesine zor günlerde, insanların pandeminin üzerlerinde yarattığı psikolojik, ruhsal etkilerinden uzaklaşmak adına sanata, sanatın önemli dalı olan müziğe ihtiyaç duydukları görülmektedir. Bu araştırma pandemi sürecinde müziğin iyileştirici etkilerini anlatmak amacıyla yapılmıştır. Araştırmada, literatür taraması yapılarak, tarihimizde müzikle terapi alanında yapılan çalışmalara yer verilmiş ve yaşadığımız bu pandemi sürecinde müziğin hangi alanlarda ve nasıl kullanıldığına dair bilgiler verilmiştir.

Anahtar Kelimeler: Pandemi, Müzik, Müzik Terapi

\section{The Improving Effects of Music in The Pandemia Process}

\begin{abstract}
It is known from past to present that art and music have physical, spiritual and therapeutic effects. In this field called music therapy, the calming, healing and unifying effects of music are used to treat people in many branches of medicine. In this pandemic process in which we, as all countries of the world, go to
\end{abstract}


history pages in every field, the unifying, fusing, healing, regenerative, therapeutic effects of music are once again noticed. In order to protect the health of people and save them from mass deaths, states have had to make restrictions in many areas in all aspects of social, cultural, economic and education. With the stay at home application, it is seen that in such difficult days when everyone is removed from the contagious effects of the covid-19 virus by living in isolation from the outside world, people need art and music, which is an important branch of art, in order to get away from the psychological and spiritual effects of the pandemic. This research was conducted to explain the healing effects of music during the pandemic process. In the research, literature review was made, and the studies in the field of music therapy in our history were included and information was given about the areas and how music was used during this pandemic process.

Keywords: Pandemic, Music, Music Therapi

\section{Giriş}

Soyut bir kavram olan sanat, her bireyin kendi iç dünyasına ve yaşadıklarına göre şekillendirebileceği, insanı insan yapan vazgeçilmez olgulardan biridir. Sanatın önemli dallarından olan müzik, insanın yaratılmasıyla var olmuş, insanlık tarihi kadar eski olduğu yapılan araştırmalarca bilinmektedir. Müziğin en önemli yapı taşı olan ses, hayatımızın her alanında bizi sarar. Rüzgar, gök gürültüsü, yağmur, kuş, araba, bebek... pek çok ses bizim duygularımızı ortaya çıkartır. Kimi zaman sevindirir, kimi zaman kızdırır, kimi zaman da korkutur. Hepsi insanın varoluşundan gelen hayati duygulardır. Bedenin sese ve müziğe verdiği tepkiler incelendiğinde her şart ve ortamda beynin mekanizmalarını harekete geçirdiği, farklı seslere ve müzik türlerine farklı cevaplar oluşurken bu tepkilerin çevresel faktörler, zaman, mekan ve kişinin duygu durumu ile değişebildiği gözlemlenmiştir (Boşnak M.\&Kurt H.A.\&Yaman S.2016.s: ) Tüm dünya ülkeleri olarak her alanda tarih sayfalarına geçtiğimiz bu pandemi sürecinde müziğin birleştirici, kaynaştırcı, iyileştirici, yenileyici, tedavi edici, etkileri bir kez daha fark edildiği düşünülmektedir. Şuan içerisinde yaşadığımız, dünyayı etkisi altına alan duygu durumumuzu ani şekilde değiştiren, Çin Halk Cumhuriyeti, Hubei Eyaleti Vuhan şehri deniz ürünleri pazarı çalışanlarında 31 Aralık 2019 tarihinde ortaya çıkan ve 'yeni koronavirüs (COVID-19)' olarak teşhis edilen (T.C. Sağlık Bakanlığı Covid-19 Rehberi, 2020: s:5) koronavirüs salgınında, insanların sağlığını korumak, onları kitlesel ölümlerden kurtarmak adına devletler, sosyal, kültürel, ekonomi, eğitim her açıdan pek çok alanda kısıtlamalara gitmek zorunda kalmıştır. Evde kal uygulamasıyla, herkesin kendi 


\section{Pandemi Sürecinde Müziğin İyileștirici Etkileri}

aile hayatında, dış dünyadan izole bir şekilde yaşayarak covid-19 virüsünün bulaştırıcı etkilerinden uzaklaştırıldığg böylesine zor günlerde, insanların pandeminin üzerlerinde yarattığı psikolojik, ruhsal etkilerinden uzaklaşmak adına sanata, sanatın önemli dalı olan müziğe ihtiyaç duydukları düşüncesi bu araştırmanın konusunu oluşturmaktadır.

\section{Amaç}

$\mathrm{Bu}$ araştırma pandemi sürecinde müziğin iyileştirici etkilerini anlatmak amacıyla yapılmıştır. Müziğin birleştirici, kaynaştırıcı, iyileştirici özelliklerinin tarihsel dönemlerdeki etkilerine de bakarak müzik terapi konusu açıklanacaktır.

\section{Yöntem}

Araştırmada nitel araştırma yöntemlerinden döküman incelemesi yapılacaktır. Araştırmalar konusunun olgu ve olayları ile ilgili bilgi içeren belgeleri zaman ve kaynak tasarrufu yapmak için, görüşme gözlem yöntemlerini kullanmadan sadece belge inceleme yoluyla gerçekleştirebilir (Yıldırım ve Şimşek, 2008, s. 188). Araştırma konusuyla ilgili raporlar, kitaplar, arşiv dosyaları, video ve ses kayıtları, fotoğraflar gibi belgeler özgünlüğü kontrol edilerek sistematik bir şekilde analiz edilmelidir (Karataş, 2015, s.11). Araştırmada yaşadığımız bu pandemi sürecinde müziğin hangi alanlarda ve nasıl kullanıldığına dair bilgiler verilerek, Türk ve Dünya tarihimizde müzikle terapi alanında yapılan çalışmalara yer verilmiştir. Araştırmaya pandemi süreci ve müzik başlığıyla pandemi sürecinde müziğin etkileri anlatılarak başlanıp, müzik terapi ve tarihi açıklanacak sonuca uygun öneriler geliştirilecektir.

\section{Pandemi Süreci ve Müzik}

Şu an ülkemizi ve dünyamızı esiri altına alan, tüm yaşantımızı değiştiren koronavirüs salgını nefes alma, yaşama, çalışma gibi hayatımızın her alanını farklı bir boyuta taşıdı. Ülkemizde ilk olarak 11 Mart 2020 tarihinde koronavirüs vakası görüldü ve aynı gün Dünya Sağlık Örgütü tarafindan "pandemi”" (neredeyse kontrolden çıkmak üzere ve çok yayılmış olan salgın hastalık) olarak ilan edildi. Tüm dünyada uçuş yasakları başladı (Budak F. Korkamz Ş. 2020.s:67) Virüsü diğerlerinden 
ayıran ise çok hızlı yayılması ve özellikle kronik hastalı̆̆ı olan 65 üstü bireylerde ölümle sonuçlanmasıydı. (Çobanoğlu N.2009: S:29-38) çalışmasında, araştırmalarda ölümcül olabilen virüslerle ortaya çıkan bulaşıcı hastalıklarda etik sorumluluklar ve ilkelerin gerekliliğinin önemine değinmiştir. Dünya sağlık Örgütünün resmi sayfasında her ülke için günlük olarak güncellenen veriler, vaka/ölüm sayıları ile giderek artan bir şekilde olması sebebiyle, uluslararası sağlı ve güvenlik konuları göz önünde tutularak, salgının ortaya çıktı̆̆ı andan itibaren her ülke kendi içerisinde katı bir biçimde uygulanan önlemler almak zorunda kalmıştır. Arttırılan sınır güvenlikleri ve ülkelere giriş çıkış yasakları, seyahat kısıtlamaları, eğitim-öğretime ara verilmesi, karantinalar, iptal edilen ya da iptali söz konusu olan ulusal ve uluslararası düzeyde spor ve sanat etkinlikleri, kamusal alanlarda yapılan dezenfeksiyon uygulamaları, sokağa çıkma yasakları bunlardan bazılarıdır (Acar, 2020.S:10)

Koronavirüs ortaya çıktığı andan itibaren başta sağlık alanında olmak üzere hızla çok sayıda yeni bilimsel çalışma yapılmış ve yapılmaya devam etmektedir. Ulusal yönetimlerin aldığı ve uyguladığı kararlar, Dünya Sağlık Örgütü tarafından salgının durdurulması ve kontrol altına alınmasına yönelik eylemlerde çok büyük önem taşımaktadır. Dünya Sağlık Örgütünün yaptığı bilimsel çalışmalar incelendiğinde sağlık, ekonomi, eğitim vb. pek çok alanda yapılan kısıtlamalar ve kurallar tüm bireyleri ruhsal açıdan yorduğu bir gerçektir. İnsanlar evde izole olduğu dönemde sosyal iletişim ağlarıyla sosyal faaliyetlerle yaşama tutunmaya devam etmektedirler (Deniz K.A. 2020.S:199) Covid-19 salgını nedeniyle yapılan bu kısıtlamaların insanlar üzerinde etkilerini inceleyen çalışmalarında (Erdoğdu Y. \& Koçoğlu F. \& Sevim C. 2020. S:12) evde kalma, izolasyon, kısıtlamalar ve katı kurallar neticesinde beraber yaşanan kaygı ve anksiyete bozukluklarının önüne geçmek için bireylerin psikolojik kaygılarını anlamak, dayanıklılıklarını sürdürebilmeleri için bu ihtiyaçlarının karşılanmasına imkân verilmesinin önemini vurgulamaktadırlar. Küreselleşme ile birlikte ulaşımın artması hastalığın hızla yayılmasını arttırmıştır olsa da teknoloji, iletişimin olanaklarının artması bu hastalıktan korunma ve tedavi yöntemlerinde bilgilenme konularının önünü açmıştır (Çobanoğlu N.2020.s:50). Eğitime ara verildi, kültür sanat etkinlikleri, konserler iptal edildi, dünya bir anda sessiz ve issiz bir alana dönüştü. Ama salgının patlamasıyla parlayan büyüyen bir alan vardı ki oda teknoloji, internet kullanımı, sosyal medya yirmi birinci yüzyılın getirdiği imkanlarla insanlar evlerine kapandılar diye düşünürken aslında bilgisayar, tablet ve telefonlarına kapandılar. Teknoloji bu dönemi çok fazla hasar almadan atlatmamıza mı sebep olmuştu? Bu durum yeni araştırma konusu olarak 


\section{Pandemi Sürecinde Müziğgin Iyileştirici Etkileri}

karşımıza çıkmaktadır. Teknoloji, öğrenmeyi yer ve mekân kavramını ortadan kaldırarak, öğrenmenin hiçbir zaman geç olamadığını vurgulayan yaşam boyu eğitim modelinin de önünü açmıştır. Öğrenmeyi kişiye özel hale getirerek, bireyi en üst düzeyde motive etmektedir. İnternet ve sosyal medya bireylerin istedikleri şeyi, istedikleri zaman, yaşamlarının her aşamasında öğrenmelerine olanak sağlar. (Tecimer B.2006.s:1) İnternetin gelişmesi ile birlikte bireyler nerdeyse artık tüm ihtiyaçlarını sosyal medya platformları üzerinden gidermeye başlamışlardır. Konser, tiyatro ve dinleti gibi eğlence faaliyetleri de bireylerin moral ve motivasyonlarının arttırılması açısından sosyal medya üzerinden gerçekleştirilmekte canlı çevrim içi konserler gerçekleştirilmektedir. Instagram'da “\#evdekalmüziklekal” etiketi altında müzik faaliyetlerine ilişkin 17.4 bin gönderi yer almaktadır (Deniz K.A. 2020.S:199). Koronavirüs salgını nedeniyle 12. Mart tarihinden itibaren ülkemizde de yapılacak olan sanatsal etkinlikleri iptal edilmeye başlamıştır. Aşağıda onlardan bazılarına yer verilmiştir.

Devlet Opera ve Balesi Genel Müdürlüğü, Güzel Sanatlar Genel Müdürlüğü ve Devlet Tiyatroları Genel Müdürlüğü

IX. İstanbul Uluslararası Opus Amadeus Oda Müziği Festivali

Bilkent Senfoni Orkestrası'nın 14, 21, 28 Mart ve 3 Nisan 2020 tarihli konserleri iptal edildi.

14 Mart 2020 tarihinde CRR Konser Salonu'nda gerçekleşecek olan 4. Uluslararası Piyano Yarışması İstanbul Orchestra'Sion Gala Gecesi iptal edildi.

İstanbul Büyükşehir Belediyesi, Karşıyaka Belediyesi, Ataşehir Belediyesi, Çankaya Belediyesi,

Hikmet Şimşek Sanat Merkezi, İş Sanat, Enka Sanat, düzenlenecek olan tüm sergi, tiyatro ve atölye gibi tüm kültür-sanat etkinlikleri ertelendi ve iptal edildi (Andante 2020).

Pandemi yani adına dünyanın sağlık savaşı diyebileceğimiz bu günleri ilk günlerden itibaren sanatın ve müziğin birleştirici, kaynaştırıcı, iyileştirici etkileri tedavi etmeye başladı. Covid-19 salgınıyla birlikte uygulanan sokağa çıkma yasakları, dünyanın pek çok ülkesinde eve kapanan müzisyenler, müzik eğitimcileri, sanatçılar internet ortamından canlı konserler düzenlemeye başladırlar. Opera sanatçıları, müzisyenler evlerinin balkonlarından konserler vererek balkon konserlerini hayatımıza kattılar. Fransız soprano Veronica Antonelli, Paris'teki evinin balkonundan komşularına sürpriz bir jest yaparken, 'bella ciao' şarkısıyla İtalya'nın salgın karşısındaki mücadelesine destek verdi (2020 internet). Müzik eğitimcileri ve sanatçılar çevrim içi yapılan canlı konserlerle hem halkı hem kendilerini motive ederek ruh sağlığımızı korumaya, müziğin iyileştirici etkilerini yaymaya başladılar. Sanat her şeyi iyileştirirdi. Birçok ülkede proje 
şeklinde gerçekleştirilen konserlerle dostluk, barış konserleri verildi. Türk, Sırp, İtalyan ve Çinli orkestra ve koro sanatçıları, "Uzak Ama Birlikte" projesi kapsamında internet üzerinden evlerinden katılarak konser verdi (2020 İnternet) .

\section{https://www.youtube.com/watch?v=UHA8bdHbIwI}

Herkes birbirine uzaktı ve aynı sağlık savaşının içindeydi ama müziğin yoluyla dostluk, barış mesajı tüm dünyaya yayıldı. Pandeminin sanatlarına engel olmasına izin vermeyen müzisyenler çevrimiçi konserlerle insanlara moral oldu. İtalyan opera sanatçısı Andrea Bocelli, corona virüs salgını nedeniyle paskalya konserini internet üzerinden verdi. https://tr.euronews.com/2020/04/14/covid-19-krizine-muzikle-direnis-cevrimici-ve-balkon-

\section{konserleri}

Fransız orkestrası YMCA'nın Village People parçasının orkestra versiyonunu seslendirirken çevrimiçi konsere orkestra şefleriyle birlikte katıldılar (2020 İnternet)

https://tr.euronews.com/2020/04/14/covid-19-krizine-muzikle-direnis-cevrimici-ve-balkon-

\section{konserleri}

Berlin flarmoni orkestrası da konserlerini internet üzerinden vermeye başladı. https://www.digitalconcerthall.com/en/concerts

Türkiye' de de salgın sebebiyle ertelenen, iptal edilen konserler internet üzerinden çevrimiçi olarak düzenlenmeye başlandı. Ünlü keman sanatçısı Cihat Aşkın kendi internet sitesi üzerinden neredeyse her gün akşam saatlerinde canlı konserler verdi. Piyano sanatçısı Gülsin Onay çevrimiçi konserler düzenledi. https://www.youtube.com/watch?v=UHA8bdHbIwI Pandemi nedeniyle "Evde Kal” günlerinde konserlerini sergileyemeyen kültür ve sanat elçileri çevrimiçi yapılan mini konserleri aracılığıyla toplumsal dayanışmayı hayatımıza soktu (KUMID 2020). Ülkemizdeki pek çok üniversitede "evde kal" sloganını desteklemek üzere videolar hazırlayarak insanları güçlendirmeye, birlik olmaya çağırdı. Şarkılarla, şiirlerle toplumumuza destek oldular. https://www.youtube.com/watch?v=ATCH60Z0M1k

Evimizden çıkmadan izleyebileceğimiz konserler, gidebileceğimiz müzeler başlıklı pek çok internet sitesi insanlara konserleri ve etkinlikleri takip etme olanağı sağladı. Bu canlı konserleri hala devam ettiren sanatçllarımız bulunmakla birlikte sosyal mesafe ve hijyen kurallarına dikkat ederek konserler haziran ayından itibaren girilen normalleşme süreci içerisinde az da olsa başlamıştır. İstanbul Kültür Sanat Vakfı olarak bu sene 48.si düzenlenen İstanbul müzik festivalleri bu sene dijital ortamdan gerçekleştirilmiştir. Festivalde tüm sağlık, hijyen önlemleri alınarak ilk 
kez seyircili bir konser düzenlenmiştir. Normalleşme süreci yaz aylarına denk geldiği için tüm sağlık ve hijyen önlemleri ile açık hava konserleri düzenlenmiştir. Müzik sadece bireyleri tek başına etkilemekle kalmayıp toplumları, kültürleri etkileştirip şekillendiren, tanıtan bir alandır. Toplumlar kimliklerini korumak, kültürlerini kuşaktan kuşağa aktarmak kültürel bir belleğe ihtiyaç duyarlar. Müziğin yapı taşlarını oluşturan "ezberleme" (kaydetme), "tekrarlama", "hatırlatma" (çağırma), "canlandırma" ve "devamlılık oluşturma" kültürel belleğin oluşumu ve aktarılmasına katkı sağlamaktadır. (Akın, B. 2018.s:114). Müzik, içerisinde farklı kültürleri barındıran ve kendine özgü dokusunu yansıtan evrensel bir iletişim aracıdır (Çuhadar, 2008). Müzik, insan üzerindeki etkileri, beyin üzerinde yarattığı çalışma potansiyeli, resim/heykel/sinema/tiyatro gibi farklı alanlarda eserin duygularını yansıtma özelliğinin olması, tedavi edici yönü, ani duygu değişimlerini sağlamaya yardımcı olması gibi pek çok özelliklerinden dolayı, görsel sanatlardan sinema, televizyona kadar birçok alanda kullanılmaktadır (Baydağ C. 2019.s:371). Hayatımızda bireysel, toplumsal, kültürel her anlamda bizi etkisi altına alan müzik sayesinde en küçük duygu değişimlerini bile müzikle ifade etmemiz mümkün. Örneğin, korku dolu bir film sahnesinde kullanılan müziğin değişimi, farklı bir tonda daha hareketli bir müziğin eklenmesiyle ani duygu değişimlerini hissedebiliriz. Korku dolu olan o an duygu dolu bir ana çevrilebilir. Yapılan pek çok araştırma müzik ve duygudurum ilişkisinin önemini vurgulamaktadır. Müzik, sadece insanlar arasındaki iletişimi geliştirme potansiyeline sahip olmakla kalmayıp, çeşitli dönemlerde tedavi amaçlı da kullanılmıştır. Müzik ve müziğin iyileştirici etkileri, tarih çağları boyunca kullanılan, merak edilen ve araştırılan bir konu olmuştur.

\section{Müzik Terapi ve Tarihi}

Müzik terapi kavramı, Yunanca hastaların bakımı ve tedavisi gerekli çareleri bulmak anlamına gelen terapi ile müzik sözcüğünün birleşmesinden oluşur (Benenzon, 1991: 13). Müziğin tedavi amacıyla kullanıldı̆̆ en eski medeniyetlerin başında Sümerler, Babiller, Asurlar, Şamanlar, Çinliler, Eski Mısır ve Yunanlılar, milattan sonra ise Endülüs, Emevi, Selçuklu ve Osmanlılar gelmektedir. Sanat-terapi yöntemlerinden biri olan müzik terapi, insanlar arasındaki iletişimde ortak bir dil ve güç olan müzik sanatı ile insanların duygularına yaklaşabilme, hissedebilme ve iletişim kurabilmelerinde fayda sağlayan önemli bir alandır. Çünkü müzik psikolojik rahatlama sağlayıcı, insanın bozulmuş olan ruhsal dengesini yeniden kurabilmesini ve çevresiyle uyumunu 
arttıran bir araçtır (Özçevik, 2007, s: 3). Müziğin fiziksel ve özellikle ruhsal rahatsızlıklarda tedavi amaçlı kullanımını, insan ruhu üzerindeki etkisi tarihin her döneminde merak uyandıran ve araştırılan bir konu olmuştur. Müziğin tedavi amaçlı kullanılması tarihte antik dönemlere kadar uzanmaktadır. Müzik ruhun gıdasır. İnsan yaşamında müzik olgusunu Uçan (1996) "İnsan müziğin, müzik, insanın özü” şeklinde dile getirmektedir. Nightingale; 1şık, temiz hava, beslenme gibi temel gereksinimlerle resim, çiçek, müzik gibi çevresel etmenleri, beden ile ruhun bağlantısını geliştirmek için kullanmıştır (Inger-soll \& Schaper, 2013). Müzik biyolojisi araştırmaları doğrultusunda doğru tempoda bir müzik dinlemek, enstrüman çalmak ya da dinlemek, müzikle uğraşmak beyinin hem sağ hem de sol bölümlerini harekete geçirerek en yüksek öğrenme/ anımsama etkisi oluşturur. Normal öğrenme potansiyelini beş kat arttırırken beyin düzenli seslerle rahatlar ve zihnimiz daha kolay konsantre olabilir (Yazıcı D.2017. s:101) 1800lü yılların başlarında Florance Nightingale, hastaların iyileşmesinde, tedavi sürecinde ve konforu korumak adına müzik terapinin önemini vurgulamış ve insan beraber kullanılan nefesli ve yaylı çalgıların hastalar üzerindeki olumlu etkilerine değinmiştir. Müzik terapinin sağlık üzerine etkilerine dair yapılan farklı çalışmalarda, kan basıncını düşürdüğü, uyku kalitesini artırdığı, stres ve depresyon puanlarında önemli düşüş kaydettirdiği, bellek sorunu, işitme sorunu yaşayan hastalarda faydalı olduğu üzerinde durulmuştur. (aktaran. Öcebe K.D.\& Kolcu M.\& Uzun K.2019. s:114). Müzik ve psikoloji alanında ilk ve önemli bir çalışma, araştırmacıların, her iki alanda da ortak bir paydada buluşması, sorunların çözümü adına adım atılması ve disiplinlerarası çalışmaların başlatılması için 1978, 1979 ve 1981 yıllarında Ann Arbor Sempozyumu düzenlenmiştir. Kendi alanlarındaki eksiklikleri düzeltme isteği ve alan araştırmacılarını bir araya getirme girişimi, gelişmelere önayak olmuştur. (Eden, 2016). Çocuklarda görülen bazı psikiyatrik bozukluklarda da, özellikle zekâ geriliği, davranış bozuklukları ve öğrenme bozukluklarında müzik terapisi ile ruhsal, duygusal ve toplumsal gelişime katkıda bulunarak, sevindirici sonuçlar alınabilmektedir. Modern psikiyatrinin en önemli konularından biri olan müziğin terapik etkileri, problemli kişileri topluma kazandırmak, gerçek yaşamla ilişkilerini sağlamak adına giderek büyük anlam ve önem kazanmaktadır (Özçevik, 2007.s:1). Müziğin tıp bilimindeki önemini psikiyatride ilk olarak inceleyen 1848 yılında Praglı Müzik terapist Raudnitz olmuştur. 1959'da Viyana'da, 1973'te Almanya'da “Müzik-TerapiDerneği" kurulmuştur. Çin ise müzik tedaviyi teknoloji ve yenilikçi olarak anestezilerdeki elektro akapunktur tedavilerinde kullanmaktadır (Doğan, 2006: 66-123). Dünyada müzikle tedavi uygulamalarına bakıldığında Norveç, Letonya, İngiltere, Japonya, Arjantin, Brezilya olmak üzere 
pek çok ülkede müzikle tedavi konusunda üniversitelerde eğitimler, seminerler verilmiş, yüksek lisans programları açılmış, sertifikalı eğitim programları düzenlenmiş ve çeşitli dernekler açılmıştır. Türkiye'de akademik eğitim veren bir kurum bulunmamasına karşın TÜTEM ve TÜMATA (Türk Musikisini Araştırma ve Tanıtma Grubu) olan iki özel merkez Türk Müziği ile tedavi çalışmaları yapılmaktadır. (Uçaner B. \& Öztürk B.2009. s:6-10). Türk müzik tarihi içerisinde müzikle tedavi uygulamalarına bakacak olursak, Orta Asya Türk Kültürü en az M.Ö. 1700 y1llarına kadar uzanan yaklaşık 6000 yıllık uzun bir süreyi içermektedir. Kopuz veya saz çalgıları tedavi edici olarak iyi ruhları çağıran, kötü ruhları kovan, davullar hasta tedavisinde, dini törenlerde şamanlar davul çalarak ruhları hükmü altına alır, ölülerle, şeytanlarla, cin ve perilerle irtibat kurarak hastalara şifa dağıttıklarına inanırlardı. Kaşgar, Kırgız Türklerinde Baksı olarak adlandırılan seanslarla müzik, şiir, taklit ve dansı sanatkâr bir biçimde birleştirerek hastayı iyileştirmeye çalışmışlardır (akt. Somakçı P. 2019.s: 132). Selçuklu ve Osmanlı döneminde müzikle tedavi çok kullanılan bir alandır. Özellikle akıl hastalıklarının tedavisinde müzikle tedaviye yer vermişlerdir. Selçuklu döneminde, Şuuri Hasan Efendi "Ta'dil-ül Emzice” isimli kitabında musikinin aynı zamanda tıpla alakalı olduğundan bahsetmektedir. Makamların ne tür hastalıklara iyi geldiğini belirlemiş, aynı zamanda da makamların insan sınıfını etkilediğini şu şekilde açıklamıştır:

Rast Makamı: Felç hastalığında tedavi amaçlı kullanılır.

Irak Makamı: Sert mizaçlılara ve kalp çarpıntısına iyi gelir.

İsfahan Makamı: Anıları canlandırır ve zihin açıklığı sağlar.

Zirefgent Makamı: Sirt ve eklem hastalıkların tedavisinde kullanılır.

Rehavi Makamı: Baş ağrılarına ve kalp çarpıntısına iyi gelir.

Büzürk Makamı: Zihni açar ve Ateşli hastalıkların tedavisinde kullanılır.

Neva Makamı: Kadın hastalıkları tedavisinde kullanılır.

Zengule Makamı: Kalp hastalığına iyi gelir.

Hicaz Makamı: İdrar yaparken zorlanmaya yardımcı olur (Şengül, 2008, s. 50-52).

Müzik ile tedavi yapılan merkezlerinden biri olan Divriği Darüşşifası UNESCO'nun “Dünya Kültür Mirası" listene 1985 yılında adına ilk üçe yazdırmıştır (Erer \& Atıcı , 2010, s. 30-31).

Osmanlı döneminde de müzikle tedavi alanına hekimler ilgi göstermişler. Makamların insan üzerindeki etkilerini hastalıklara, güne ve gezegenlere göre sinıflandırmışlardır. $\mathrm{Bu}$ sinıflandırmaya göre, 
Rast Makamı: Felç hastalığına iyi gelir. İnsana neşe ve huzur verir. Güneş iki mızrak boyu yükselince uygulama yapılır. Etkisi kemik ve beyin üzerindedir.

Rehavi Makamı: İnsana ebediyet duygusu verir. İmsak zamanında etki gösterir. Baş ağrısına, doğuma ve akıl hastalıklarında fayda gösterir.

Zengule(Zirgüle) Makamı: Kalp, menenjit ve beyin hastalıkların tedavisinde kullanır. Sabah ve öğle zamanları arasında etkilidir. Mide ve karaciğerin rahatlamasını sağlar. Ayrıca ruh hastalıkların tedavisinde de etkilidir.

Hüseyni Makamı: Sakinlik ve rahatık hissiyatı uyandırır. Sabah gün ağarırken etki gösterir. Kalp, mide ve karaciğer hastalıklarında etkilidir. Rahatlık, sakinlik ve huzur verir. Otizm ve spastik tedavilerinde kullanılır.

Saba Makamı: Mutluluk ve kahramanlık hissiyatı verir. Seher vaktinde etki gösterir. Kalp hastalıkların tedavisinde kullanılır. Aşk duygularını ifade etmede kullanılır. Ruh hastalıkların tedavisinde etkilidir.

Uşşak Makamı: Mutluluk, güç ve kahramanlık hissiyatı verir. Öğle zamanı etkisini gösterir. Uyku için faydalı olup, rahatlama hissi verir.

Hicaz Makamı: Alçak gönüllük hissiyatı verir. Yatsıdan sabaha kadar olan zaman aralığında etkilidir. Düşük nabız atışına iyi gelir.

İsfahan Makamı: Zihin açıklığına ve geçmişi hatırlamaya yardımcı olur. Hareket yeteneği sağlar. Gün batarken etkilidir.

Irak Makamı: Menenjit, beyin ve akıl hastalıkların tedavisinde etkilidir. Korkuyu gidermede lezzet ve düşünmede yararlıdır. Akşamüstü etkisini gösterir.

Buselik Makamı: Güç ve kuvvet vericidir. Bel ve kulunç ağrılarına yararlıdır. Kuşluk vakti etkilidir. (Güneşin doğuşundan yaklaşık 40-50 dakika sonra.)

Büzürk Makamı: Ateşli hastalıkların tedavisinde etkilidir. Zihni rahatlatıp, korku duygusundan uzaklaştırır. Yatsıdan sonra etkilidir. Beyin hasarı sonrası oluşan durumlarda kullanılır.

Neva Makamı: Rahatlık duygusu verir. Zihindeki kötü fikirleri yok eder. Güç ve kahramanlık duyguları verir. Akşam vakti etki gösterir. Ergenlik çağındaki kızların hastalıklarında uygulanır. Acemaşiran Makamı: Fecirden kuşluk vaktine olan zaman diliminde etkilidir. (Güneş doğmadan önceki tan yerinin ağarmasından önceki vakitten güneş doğduktan sonra 40-50 dakika sonra olan vakit). Ağrıyı hafifletir. Duyguların canlanmasını sağlar. İlham duygusu verir. 


\section{Pandemi Sürecinde Müziğin İyileştirici Etkileri}

Zirefgent Makamı: Uyku zamanı etki gösterir. Sırt ve eklem ağrılarını gidermede yardımcı olur. Akıl hastalıkların tedavisinde ve ruhsal anlamda dinginlik verir (Birkan, 2014, s. 40-42).

Tarihin her döneminde müzik terapi tıp biliminin önce psikiyatri olmak üzere neredeyse her alanına girmiş, uygulanmış ve yardımcı tedavi tekniğgi şeklinde uygulanmıştır. Müziğin dinlendirici, eğlendirici, eğitici, insanı bilişsel, fiziksel, psikolojik her yönden etkisi tıp bilimin konuları arasına girmiştir. Müzik Terapi halen araştırmalara konu olan, merak edilen ve uygulanan önemli bir alandır.

\section{Sonuç ve Tartışma}

Müzik terapi, tarihin ilk dönemlerinden bu yana insanoğlunun kullandığı ve araştırdığı önemli bir alandır. Sanat dallarını alternatif tıp olarak kabul gören sanat terapisi alanı, sanatın iyileştirme gücü, sanat-sağlık alanlarının kaynaşması, bir tedavi yöntemi olarak kullanılması sağlık alanında yapılan bilimsel araştırmalarla kanıtlanmıştır (Kahraman M.E. \& Bostancıoğlu B. 2017.s: 151). Müziği oluşturan seslerin dizilişlerindeki uyum, ritim, tempo her bireyde yaşantıları oranında farklı duygular hissettirir. Bu açıdan özeldir ve herkese farklı ulaşır. Dünya, doğa, hayatımız seslerle doludur. Bu seslerin içerisinde var olduğumuz için insan müzikten bu kadar etkilenir. Hayatın her alanında müziği ve bizde bıraktığı etkilerini görebiliriz. Bir dışavurum aracı olan sanat, kişinin duygu durumunu somut biçimlerde yansıtmasıdır. Duygusal olarak bloke olmuş bir kişi ya da hasta sözel olarak kendini ifade edemediği kilit durumlarda, kişinin duyu organlarını aktif olarak kullanmasına yardımcı olur (Kahraman M.E. \& Bostancığlu B. 2017.s: 151).Müziğin insanları bilişsel, fiziksel ve ruhsal etkilemekle kalmaz toplumda birleştirici, kaynaştırıcı, belirleyici rol oynar. Aralık ayından bu yana Çin' de başlayarak dünyayı etkisi altına alan koronavirüs (covid-19) salgınıyla tamamen değișen hayatımız artık internet üzerinden yapılan eğitimle, konserlerle, görüşmelerle devam etmektedir. Şu an bu belirsizlik halen devam etmektedir. Her ne kadar bu salgını karantinalarla evde de geçiriyor olsak da teknoloji ve internet ağı sayesinde eğitimden, sosyal hayata kadar ihtiyaçlarımızı karşılıyoruz. Çevrimiçi yapılan konserlerle salgının üzerimizde yaratmış olduğu baskıyı, sıkıntıyı atmaya çalışıyoruz. Sanatın müziğin iyileştirici etkileriyle hayata tutunmaya çalışıyoruz. Hasta hakları, Bireylerin hem bedensel hem ruhsal sağlıklarının önemli olduğu bu salgın sürecinde toplum sağlığını gözetecek önlemleri almalıyız. Dünyanın bir köşesinde bir insanı etkileyen bir hastalık kısa sürede küresel 
bir pandemiye dönüşebiliyor. Tedavi, aşı, çalışmalar sürerken her bireyin sağlığına kavuşmasının önemi yanında insanlığın evrilmesi açısından da önemli bir değersel dönüşüm yaşayacağız (Çobanoğlu N.2020.s:52). Bu araştırmada pandemi sürecinde müziğin insanları iyileştirici, birleştirici, tedavi edici yönüne değindik ama salgından dolayı müziğin, sanatçıların yara aldığı pek çok alanda var. Yapılamayan konserler, bu konserlerde yer alan sanatçılar, sanat emekçilerinin işlerinin birden durması, sektör çalışanları aniden gelirsiz ve güvencesiz bir şekilde ortada kalmaları, ekonomik boyutu, müzik eğitimi boyutu online işlenen müzik dersleri ve daha birçok konu, yaşanan bu belirsizlik devam ettikçe müzik alanının sorunları olarak yer alacaktır. Bu çalışmanın müzik ve pandemi ilişkisi ile ilgili yeni yapılacak çalışmalara ışık tutacağ düşünülmektedir. Salgın nedeniyle bu önlemlerin alınması, evde kal sloganıyla insanların evlerinde yaşamaya başlamasıyla birlikte burada tek büyüyen teknoloji, internet, sosyal ağlar gibi gözüküyor. Müzik tek başına tedavi edici olamaz ancak tedaviyi destekleyici bir yan olarak düşünülmeli. Tamamlayıcı ve Alternatif Yaklaşım olarak tanımlanan TAT yaklaşımları bilişseldavranışsal yaklaşımlar, bedensel fonksiyonları iyileştirmek ve semptomları hafifletmek amacı ile bilişsel kapasiteyi güçlendirmede kullanılan farklı yaklaşımları içermektedir. Meditasyon, dua etme, zihinsel şifa ve sanat terapi, müzik terapi veya dans terapi gibi Bilişsel-Davranışsal Yaklaşımları içerisine alan TAT yaklaşımı olarak günümüzde geleneksel tıbbın bir parçası haline gelmiş̧tir. $\mathrm{Bu}$ yaklaşımların kullanımı hastalarda var olan anksiyeteyi, duygu-durum bozukluklarını ve kronik ağnıı azaltmakta ve hastaların yaşam kalitesini iyileştirmektedir (http://nccam.nih.gov). Küresel ölçekli bir dayanışma ile bu küresel sorunu aşabiliriz (Çobanoğlu N.2020.s:50). Bu dayanışmayı sağlayıcı, toplumları birleştirici en önemli unsurlardan birini müzik olarak düşündüğümüzde içinde bulunduğumuz bu küresel sağl1k sorununu sanatın, müziğin iyileştirici etkileri ile sarabilir ve atlatabiliriz. 


\section{Kaynaklar}

Acar Y.(2020). Yeni Koronavirüs (Covid-19) Salgını Ve Turizm Faaliyetlerine Etkisi Güncel Turizm Araştırmaları Dergisi Cilt: 4, Sayı: 1

(M29)Akın B. (2018). Kültürel Bellek Ve Müzik. Eurasian Journal of Music and Dance (13),101117

Andante (2020) COVID-19 salgını nedeniyle iptal edilen kültürel etkinliklerhttps://www.andante.com.tr/tr/9466/Covid-19-Salgini-Nedeniyle-iptal-EdilenKulturel-Etkinlikler

Baydağ C. (2019). Duygudurum Bağlamında Müzik ve İnsan Sesi. Yükseköğretim ve Bilim Dergisi. $9(3)$

Benenzon, R., 1991. Teoria De La Musicoterapia, Mandala Education, S.A, Madrid.

Birkan, z. I. (2014). Müzikle Tedavi, Tarihi Gelişimi ve Uygulamaları. Ankara Akapuntur ve Tamamlayıcı Tıp Dergisi, 40-42.

Budak F. \& Korkmaz Ş. (2020). Covid-19 Pandemi Süreci İlişkin Genel Bir Değerlendirme: Türkiye Örneği. Sosyal Araştırmalar ve Yönetim Dergisi 1, 62-79.

Çobanoğlu, N. (2009). Ölümcül Olabilen Bulaşıcı Hastalıklarla İlgili Tıbbi Araştırmalarda Etik, Sağlık Bilimlerinde Sü-reli Yayıncılık, Ed. Orhan Yılmaz, TÜBİTAK, Ulakbim, Ankara, Çobanoğlu N. (2020) Bireysel, Profesyonel, Toplumsal, Bilimsel ve Siyasal Etiği Yeniden Sorgulatan COVID-19 Pandemisi. Anadolu Kliniği Tıp Bilimleri Dergisi, Ocak 2020; Cilt 25,

Deniz K. A. (2020). Covid-19 Salgını Süresince Dijitalleşen Eğlence Anlayışı: Çevrim İçi Konserler. Stratejik ve Sosyal Araştırmalar Dergisi. 4(2), 191-206.

Durgun D. (2020). Sanat dünyasına Covid-19 molası. Boğaziçi Üniversitesi haberler.29.09.20 15.32 tarihinde https://haberler.boun.edu.tr/tr/haber/sanat-dunyasina-covid-19-molasi adresinden erişilmiştir. 
Eden, S. (2016). Duygudurum değişimlerinin dikey çift sesli aralık işitme algısına etkisi (Yüksek lisans tezi). Abant İzzet Baysal Üniversitesi, Eğitim Bilimleri Enstitüsü, Bolu.

Erer, S., \& Atıcı , A. (2010). Selçuklu ve Osmanlıda Müzik ile Tedavi yapılan Hastaneler. Uludăg Üniversitesi Tıp Fakültesi Dergisi, 29-30.

Hurley C. (2020). COVID-19' un sanatçılar üzerindeki yıkıc1 etkisi. https://www.wsws.org/tr/articles/2020/05/30/arts-m30.html adresinden erişilmiştir.

Kahraman M.E. 2020. Covid-19 Salgınının Kültür ve Sanat Organizasyonlarına Etkisi. Yıldız Journal Of Art And Design 7(1).

Kahraman M.E. \& Bostancığlu B (2017). Sanat Terapisi Yönteminin Ve Tekniklerinin Sağlık İyileştirme Gücü Üzerindeki Etkisi. Beykoz Akademi Dergisi 5(2) 150-162.

Karamızrak N. (2014). Ses Ve Müziğin Organları İyileştirici Etkisi. Koşuyolu Heart Journal 17(1) 54-57.

KUMID (2020). Corona virüs (Covid-19) ile mücadele ve Evde Kal Günlerinin Kültür-SanatKültürel Mirasa Etkileri ve Kumıd.

chromeextension://oemmndcbldboiebfnladdacbdfmadadm/http://kumid.net/storage/lwjbeGiWZv GmHdUelXLGPGPHOk9Cbwc.pdf adresinden erişilmişsir.

Öcebe D. K., Kolcu M, Uzun K.(2019). Müzik Terapi Ve Yaşlı Sağlığı. Sağlık Bilimleri Üniversitesi Hemşirelik Dergisi 1(2), 112-115

Özçevik A. (2007). Müzikle Tedavi Ve Öğrenciler Üzerindeki Terapik Etkileri. İstanbul Teknik Üniversitesi Sosyal Bilimler Enstitüsü. Yüksek Lisans Tezi.

Ingersoll, S.S. \& Schaper, A. (2013). Music: A Caring, Healing Modality. B.M. Dossey \& L. Keegan (Eds.), Holistic Nursing A Handbook For Practice. 6. Edition. Burlington, Jones \& Bartlett Learning; 397-415.

T.C. Sağlık Bakanlı̆̆ı, Halk Sağlığı genel Müdürlüğü, COVID-19 (2019-n CoV Hastalı̆̆ı) Rehberi (Bilim Kurulu Çalışması) (2020). T.C. Sağlık Bakanlığı, 25 Şubat 2020. (Erişim Tarihi: 26.02.2020). 
Erdoğdu Y. \& Koçoğlu F. \& Sevim C. (2020). Covid-19 Pandemisi Süresince Anksiyete İle Umutsuzluk Düzeylerinin Psikososyal ve Demografik Değişkenlere Göre İncelenmesi. Klinik Psikiyatri 2020.

Somakc1 P. (2003). Türklerde Müzikle Tedavi. Sosyal Bilimler Enstitüsü Dergisi.15(2)

Tecimer B. (2006). İnternet ve Yaşam Boyu Müzik Eğitimi. MÜZED Kış Sayı 15(8-9)

Uçan A.(1994). İnsan ve Müzik İnsan Ve Sanat Eğitimi. Müzik Ansiklopedisi Yayınları. Ankara.

Yazıcı D. (2017). Müziğin İnsan Beyni Üzerindeki Etkisi. Uluslararası Kültürel ve Sosyal Araştırmalar Dergisi (UKSAD), 3(1): 88-103

Yıldırım, A., \& Şimşek, H. (2008). Sosyal Bilimlerde Nitel Araştırma Yöntemleri (6.Baskı).Ankara: Seçkin Yayıncılık.

https://tr.euronews.com/2020/04/14/covid-19-krizine-muzikle-direnis-cevrimici-ve-balkonkonserleri adresinden alınmıştır.

https://www.a3haber.com/2020/03/18/fransada-etkileyici-virus-konseri-opera-sanatcisindankomsularina-muzik-ziyafeti/ adresinden alınmıştır.

http://nccam.nih.gov 